\title{
Correction to: Whitehall and the Black Republic
}

\section{Correction to:}

J. Pal Chaudhuri, Whitehall and the Black Republic, African Histories and Modernities, https://doi.org/10.1007/978-3-319-70476-0

The original version of the book was published in 2018 with some errors. All of the errors are corrected in this updated version. The most significant corrections are:

On page 121, 'As mentioned earlier, a loan of $\$ 1,7000,000$ was ... the British held nearly 1000,000 dollars' has been changed to 'a loan of $\$ 1,700,000$ was raised in Berlin, Amsterdam, Paris and London in 1912. In 1923, Liberia owed about $\$ 1,600,000$ on this loan. Of this the British had nearly 100,000 dollars.'

In chapter 7 , there was a mismatch between the numbers used in the end notes and the numbers used in the text, as the number for the first endnote was missing from the text. This has now been updated.

The updated version of this book can be found at https://doi.org/10.1007/978-3-319-70476-0

(C) The Author(s) 2020

J. Pal Chaudhuri, Whiteball and the Black Republic, African Histories and Modernities, https://doi.org/10.1007/978-3-319-70476-0_9 